\title{
EPSL
}

ELSEVIER

Earth and Planetary Science Letters 170 (1999) 49-59

www.elsevier.com/locate/epsl

\section{Mineral-magnetic record of Late Quaternary climatic changes in a high Alpine lake}

\author{
L. Lanci ${ }^{\text {a,* }}$, A.M. Hirt ${ }^{\text {a }}$, W. Lowrie ${ }^{\text {a }}$, A.F. Lotter ${ }^{\text {b }}$, G. Lemcke ${ }^{\text {c }}$, M. Sturm ${ }^{\mathrm{c}}$ \\ ${ }^{a}$ Institute of Geophysics, ETH Hönggerberg, CH-8093 Zurich, Switzerland \\ ${ }^{b}$ Geobotanical Institute, University of Bern, CH-3013 Bern, Switzerland \\ ${ }^{c}$ Environmental Physics, EAWAG-ETH, CH-8600 Dübendorf, Switzerland
}

Received 11 August 1998; revised version received 19 April 1999; accepted 20 April 1999

\begin{abstract}
The magnetic properties of a sediment core from a high altitude lake in the Swiss Alps were compared with palynological and geochemical data to link climatic and mineral magnetic variations. According to pollen data, the sediments extend from the present to the Younger Dryas, i.e., they cover more than 10,000 years of environmental change in the Alps. The major change in magnetic properties corresponds to the climatic warming of the early Holocene. High-coercivity magnetic minerals that characterize the late-glacial period almost disappeared during the Holocene and the concentration of ferrimagnetic minerals increased sharply. The contribution of superparamagnetic grains also decreased in the Holocene sediments. Similar variations in SP content and coercivity, of smaller magnitude, are found in the Holocene and are interpreted to represent minor climatic variations. Comparison with the historical record of the last 1000 years confirms this interpretation. The magnetic mineralogy, the superparamagnetic contents, and the IRM intensity in the coarse-grained, late-glacial sediments are similar to those measured in the catchment bedrock. This indicates a detrital origin. The different properties and the higher concentration of magnetic minerals in the Holocene sediments are due to authigenic phases. Magnetic properties provide a high resolution record of climatic change. They are sensitive even to small variations that are not recorded in the pollen or LOI data. Magnetic parameters show fine-scale variation and constitute a valuable supplement to conventional climatic indicators. (C) 1999 Elsevier Science B.V. All rights reserved.
\end{abstract}

Keywords: environmental analysis; glaciolacustrine sedimentation; magnetization; Holocene; climate; alpine environment

\section{Introduction}

Lake sediments provide valuable environmental archives for the late Quaternary. They offer a unique opportunity for studies of environmental and climatic change (e.g. [1-4]). Moreover, they also provide a record of geomagnetic and mineral magnetic varia-

\footnotetext{
* Corresponding author. Tel.: +41-1-633-2626; Fax: +41-1-6331065; E-mail: luca@mag.ig.erdw.ethz.ch
}

tions, and, in the last 10-20 years, they have been successfully used to investigate both changes in the Earth's magnetic field and changes in magnetic mineralogy as indicators of environmental change (e.g., [5-9]).

The Alps offer many different climate-related ecosystems over a short geographical distance because of their steep climatic gradients. In such environments, even a small climatic shift can be expected to produce large changes in biological, chemical, and 


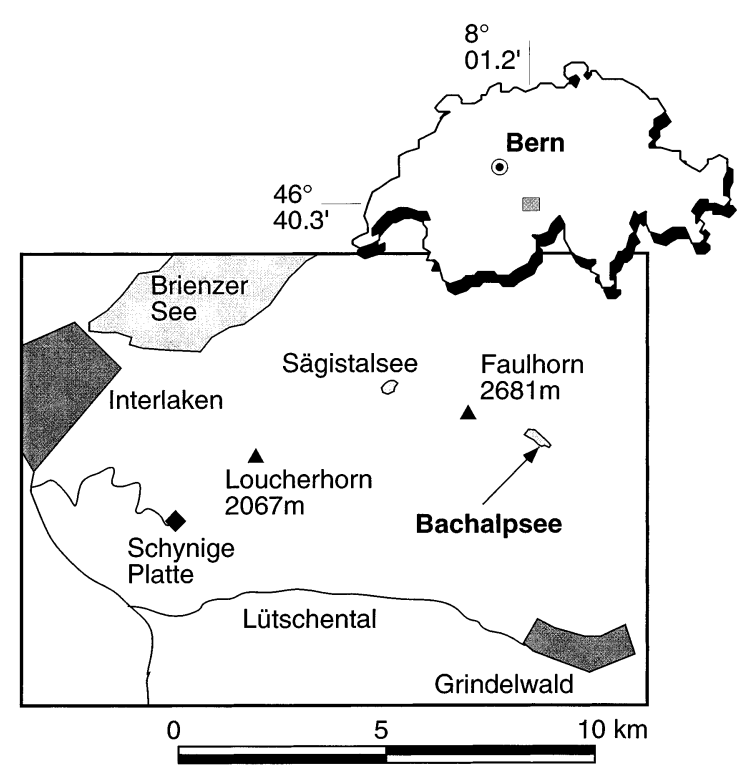

Fig. 1. Location map of the Bachalpsee.

sedimentological conditions. Alpine lakes are generally characterized by small water volumes and a long-lasting ice-cover which makes them particularly sensitive to climatic change. Therefore, they are well-suited for studies of long-term climatic dynamics. In addition, remote Alpine lakes possibly offer the only sediment archives where continuous high-resolution records of climatic variability are unaffected by human impact throughout large parts of the Holocene.

The Bachalpsee is a small lake located in the Bernese Alps (Fig. 1) at an altitude of $2265 \mathrm{~m}$, above the modern tree line which is at about 1800 $\mathrm{m}$. The lake has a maximum water depth of 15 $\mathrm{m}$, a surface area of $0.07 \mathrm{~km}^{2}$ and its hydrological catchment covers $1.87 \mathrm{~km}^{2}$. The vegetation in the catchment consists of alpine meadows and is sparse, thus favoring erosional input.

The present study is part of the interdisplinary AQUAREAL project [10], in which different proxy-indicators are being used to assess the response to environmental change and to develop a quantitative model of past climate in the Alps. The model exploits data from different sources such as biostratigraphy (pollen, plant macrofossils, cladocera, chironomids and diatoms), geochemistry, and mineral magnetism. Advantages of a multi-proxy ap- proach to environmental problems include a comparative check on results and cross calibration, which are particularly important in environmental magnetism. All samples used for mineral magnetic analysis, except the few used for thermal demagnetization, were used for geochemical analysis. In this paper, we focus on environmental changes which influence the magnetic properties of sediments, and we demonstrate that the sediment magnetism of the Bachalpsee provides a high resolution record of climate change.

\section{Environmental setting}

In May 1996, a 10-m sediment core was recovered from the frozen Bachalpsee using a modified Livingston piston corer [11]. The lithology of the core comprises coarse-grained silty sand and gravel (below $850 \mathrm{~cm}$ ) which are overlain by laminated clays and silts.

Palynological analysis provides the necessary framework for interpreting the main environmental changes and has identified well known pollen events, which have been dated with ${ }^{14} \mathrm{C}$ methods at many Swiss sites (e.g., [12]). According to the pollen analysis, the lowermost part of the core is attributed to the Younger Dryas biozone (e.g., [13]). This indicates that sites above $2000 \mathrm{~m}$ in this part of the Alps were already deglaciated during the Late Glacial. The core contains the classical Holocene forest succession. Plant macrofossil analysis has not provided any remains of trees, which indicates that this site has always been above the tree line. The pollen assemblages, therefore, are mainly influenced by the lowland vegetation through long-distance pollen transport rather than by the local vegetation. A detrended correspondence analysis (DCA) [14] was carried out on the pollen data using the program 'CANOCO' [15]. The sample scores of the first DCA axis plotted against depth give an indication of the magnitude of vegetation change through time (Fig. 2).

Loss on ignition (LOI) at $550^{\circ} \mathrm{C}$ was used to estimate the variations in organic carbon content in the sediments (Fig. 2). The low values indicate low productivity in the lake during the Pleistocene and Holocene. The major variation in LOI parallels the main climatic changes indicated by the pollen data.

A time scale was obtained for the Bachalpsee 


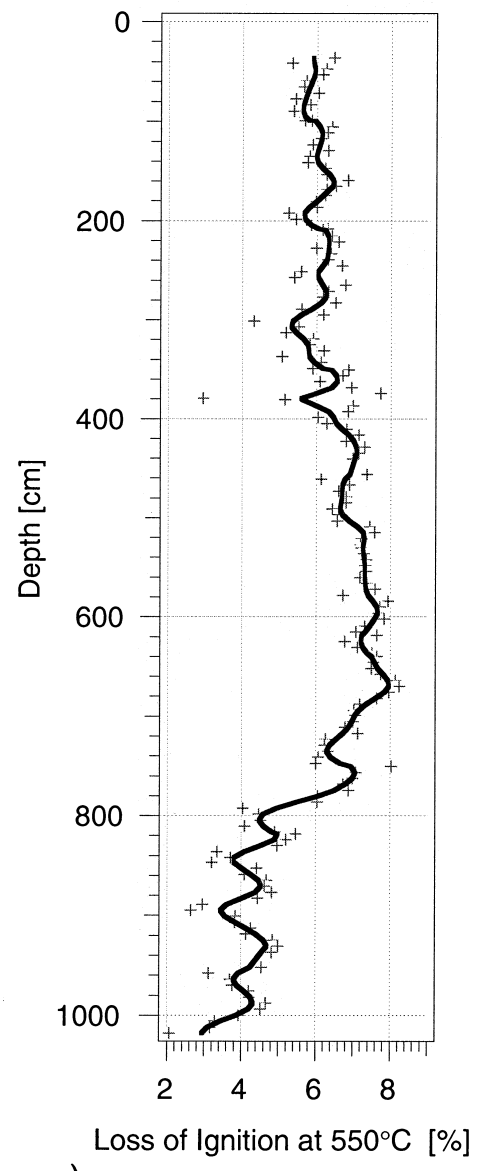

a)

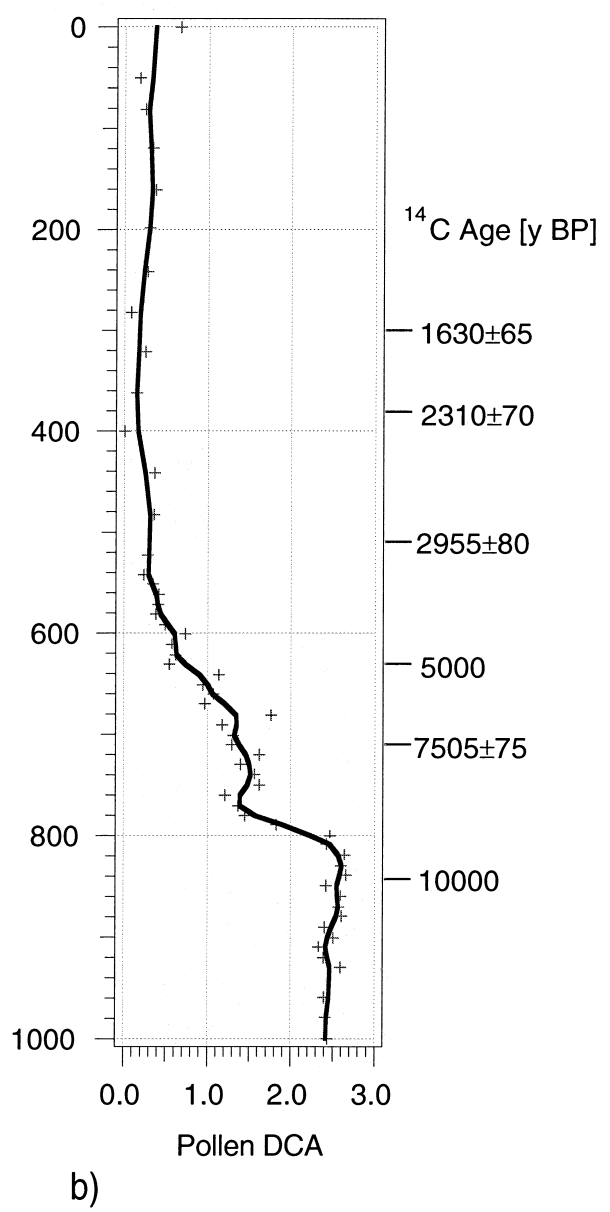

Fig. 2. (a) Loss on ignition data (LOI) at $550^{\circ} \mathrm{C}$ as a function of depth provide an estimate of the organic carbon contents in the sediments and is used as a climatic proxy. It agrees with the pollen results which indicate an increase in organic carbon content at about $780 \mathrm{~cm}$ due to a transition to warmer climate. (b) The sample scores of the first axis of the detrended correspondence analysis (DCA) carried out on the pollen data give an indication of the magnitude of vegetation change. The crosses represent the actual measurements and the line is obtained by passing the data two times throught a 5-point Gaussian smoothing filter, in this and subsequent figures.

sediments by interpolating the available radiocarbon dated levels in the core. The ages of four dated levels from the uppermost part of the core were determined by accelerated mass spectrometer (AMS) ${ }^{14} \mathrm{C}$ dating. No suitable material was found for ${ }^{14} \mathrm{C}$ dating below $700 \mathrm{~cm}$. Two levels were dated at 5,000 and 10,000 yr B.P. on the basis of 'calibrated pollen events'. No dating is available for the very bottom of the core, but palynological data suggest that it represents the Younger Dryas, thus we assume a maximum age of 11,000 years. Cubic spline smoothing [16] was used to interpolate the core ages between known ages (Fig. 3).

\section{Sediment magnetic results}

To achieve the high resolution needed for this study, about 500 sub-samples were collected from the core at $2-\mathrm{cm}$ intervals. The samples were sealed in 3.4- $\mathrm{cm}^{3}$ cylindrical plastic boxes and were stored at $4^{\circ} \mathrm{C}$ to preserve them, as far as possible, from drying and from chemical changes. All samples were weighed and their magnetic properties were computed in mass specific units. Mineral magnetic properties were studied in detail from two subsets of samples selected across the Holocene-Pleistocene boundary, which represents the most important cli- 


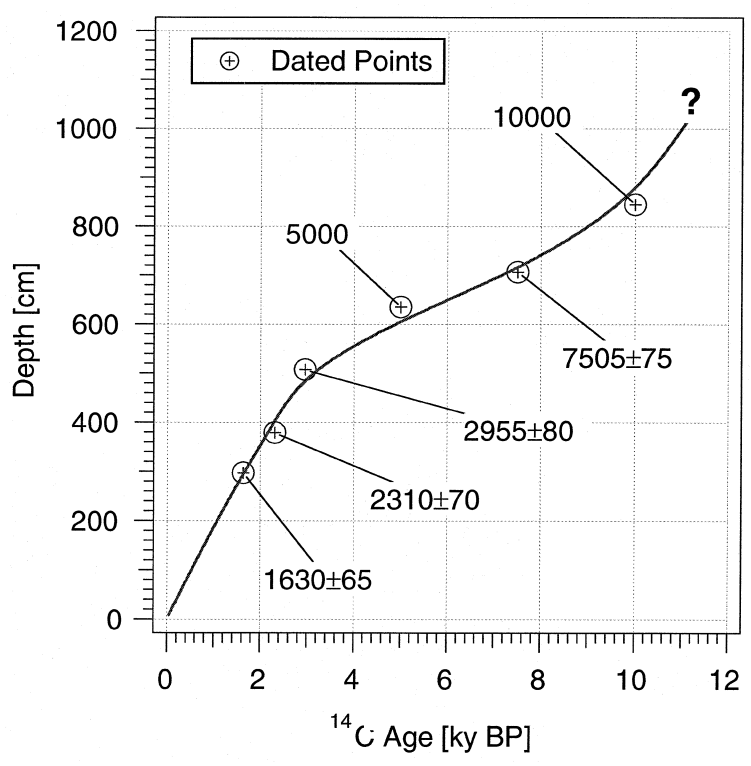

Fig. 3. Interpolated age for the Bachalpsee core. The question mark indicates the uncertainty in age at the bottom of the core.

matic change. Several magnetic parameters were used (including low field susceptibility $(\chi)$, acquisition of isothermal remanent magnetization (IRM), unblocking temperature of IRM, hysteresis loops, low temperature and high field experiments) in order to investigate how magnetic mineralogy, coercivity and grain size vary in response to climatic changes. Extraction of magnetic minerals from the sediment was unsuccessful due to the low concentration of magnetic phases and the small amount of sediment available.

\subsection{IRM acquisition and thermal demagnetization}

Stepwise acquisition of IRM was performed with an electromagnet up to a maximum field of $1 \mathrm{~T}$. The IRM acquisition curves from the Holocene (interglacial) and Pleistocene (glacial) samples have different behavior (Fig. 4a). Holocene samples are characterized by low-coercivity magnetic minerals that saturate in a field of about $200 \mathrm{mT}$; this is indicative of ferrimagnetic minerals such as magnetite, maghemite or greigite. In the Pleistocene samples, the IRM acquisition curves increase in low fields but do not saturate even at the maximum field of $1 \mathrm{~T}$. This indicates the presence of an additional magnetic
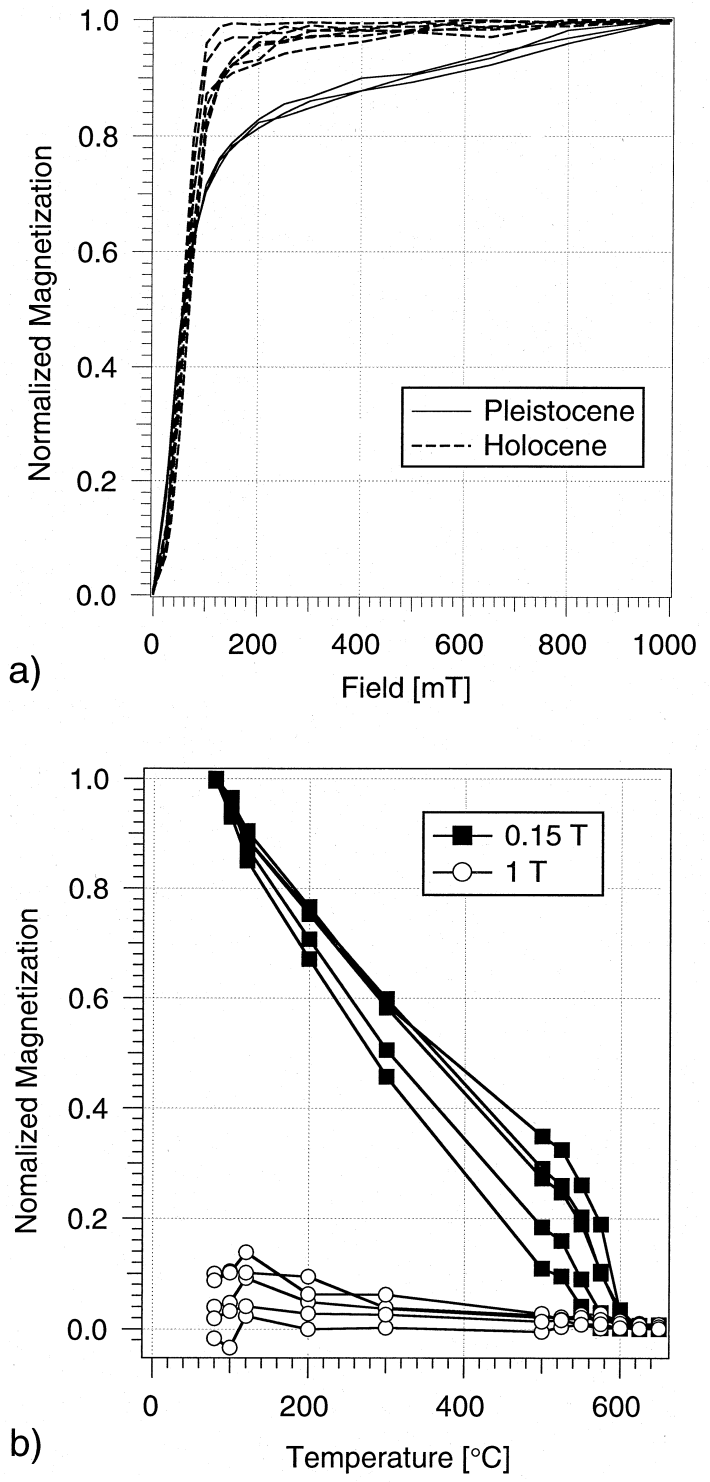

Fig. 4. (a) IRM acquisition curves for two sets of typical samples taken in the cold and warm sections of the core. The different coercivity spectra indicate differences in magnetic mineralogy and discriminate between warm and cold stages of the core. (b) Thermal demagnetization of a two-component IRM acquired along orthogonal directions in samples from the warm section of the core.

phase with very high coercivity such as hematite or goethite. Moreover, although rather variable, the IRM intensity in the Holocene samples is always much higher than in the Pleistocene samples. 
Thermal demagnetization of a composite IRM has been used to identify magnetic minerals on the basis of their unblocking temperatures [17]. The IRM acquired in two different fields of $0.15 \mathrm{~T}$ and 1 $\mathrm{T}$ along orthogonal directions in selected samples indicates distributed unblocking temperatures up to $650^{\circ} \mathrm{C}$. Almost all the remanent magnetization is carried by minerals with a coercivity less than or equal to $0.15 \mathrm{~T}$ and with a maximum unblocking temperature between $575^{\circ} \mathrm{C}$ and $600^{\circ} \mathrm{C}$ (Fig. $4 \mathrm{~b}$ ). This clearly identifies the dominant magnetic phase as magnetite. The 1-T component is usually small and is almost negligible in the Holocene samples. When present, it has a maximum unblocking temperature above $650^{\circ} \mathrm{C}$, which suggests that it is due to hematite. In a few samples, a decrease in magnetization between 200 and $300^{\circ} \mathrm{C}$ was found in the $1-\mathrm{T}$ component, which may suggest the presence of magnetic iron sulfides, although they do not seem to play a major role in these sediments.

\subsection{Zero field cooling experiment}

Low temperature experiments were used to investigate the presence of superparamagnetic (SP)

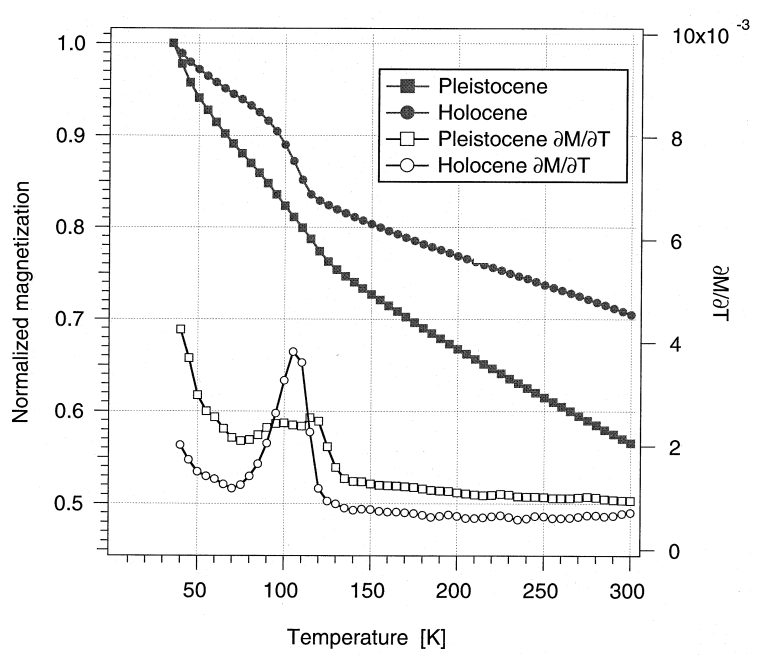

Fig. 5. Thermal demagnetization of an IRM acquired at low temperature (closed symbols) indicates the presence of SP minerals and can estimate the grain-size spectra of this mineral fraction. The first derivative (open symbols) emphasizes the phase transition at about $120 \mathrm{~K}$, which is interpreted to represent the Verwey transition of magnetite. particles by thermally demagnetizing a high field remanence acquired at $30 \mathrm{~K}$. Samples were cooled to $30 \mathrm{~K}$ in zero-field and were then magnetized in a field of $2.5 \mathrm{~T}$. The remanent magnetization was measured while the sample was warmed in nearly zero field $(<10 \mathrm{nT})$ up to $300 \mathrm{~K}$. The results for two typical samples from Holocene and Pleistocene sediments are plotted in Fig. 5. In both samples, the magnetization starts to decrease at very low temperature, which indicates the presence of a wide grain-size distribution, including very fine particles. Compared to the Holocene sample, the Pleistocene sample has a much steeper decay of magnetization, which indicates a higher concentration of fine (SP) grains throughout the whole temperature range. Magnetic transitions are emphasized by plotting the first derivative of the magnetization versus temperature. The Holocene sample has a well pronounced peak at about $110 \mathrm{~K}$, close to the Verwey transition of magnetite. A much smaller peak occurs in the Pleistocene sample at the same temperature.

\subsection{Hysteresis properties}

Hysteresis loops were measured on a Micromag alternating gradient magnetometer. All measured samples are characterized by a high paramagnetic contribution. After removal of the paramagnetic signal, the Holocene and Pleistocene samples exhibit different hysteresis loops as shown in Fig. 6a. This is also indicated by the hysteresis parameters as plotted in a Day graph [18] (Fig. 6b). In the Day plot, the Holocene samples are clustered in the upper part of the pseudo-single-domain (PSD) region, while Pleistocene samples group closer to the multidomain (MD) region; the presence of significant concentrations of SP grains in the latter may have influenced the $H_{\mathrm{cr}} / H_{\mathrm{c}}$ and $M_{\mathrm{rs}} / M_{\mathrm{s}}$ ratios. The average values of the hysteresis parameters $H_{\mathrm{c}}, H_{\mathrm{cr}}, M_{\mathrm{s}}, M_{\mathrm{rs}}$ and the paramagnetic susceptibility $\chi_{\mathrm{hf}}$ computed from the slope of the high-field linear segment of the hysteresis loops for Pleistocene (glacial), Holocene (interglacial) and transitional samples are listed in Table 1 . The dispersion of the hysteresis parameters is represented using the mean absolute deviation $\left(\sum_{i}\left|x_{i}-\bar{x}\right| / N\right)$ which is a more robust measure of dispersion than the standard deviation, especially with small sets of badly clustered data. 
Table 1

Mean hysteresis parameters high field (paramagnetic) susceptibility for different core segments. The dispersion parameter is the mean absolute deviation

\begin{tabular}{lllllll}
\hline Stage & $\begin{array}{l}\text { Depth } \\
(\mathrm{cm})\end{array}$ & $\begin{array}{l}M_{\mathrm{s}} \\
(\mathrm{A} \mathrm{m} / \mathrm{kg})\end{array}$ & $\begin{array}{l}M_{\mathrm{rs}} \\
\left(\mathrm{A} \mathrm{m}^{2} / \mathrm{kg}\right)\end{array}$ & $\begin{array}{l}H_{\mathrm{c}} \\
(\mathrm{mT})\end{array}$ & $\begin{array}{l}H_{\mathrm{cr}} \\
(\mathrm{mT})\end{array}$ & $\begin{array}{l}\chi_{\mathrm{hf}} \\
\left(\mathrm{m}_{3} / \mathrm{kg}\right)\end{array}$ \\
\hline $\begin{array}{l}\text { Holocene } \\
(N=19)\end{array}$ & $620-670$ & $1.62 \times 10^{-4} \pm 7.3 \times 10^{-5}$ & $4.55 \times 10^{-5} \pm 2.7 \times 10^{-5}$ & $24.56 \pm 3.4$ & $52.0 \pm 5.1$ & $6.84 \times 10^{-6} \pm 5.3 \times 10^{-7}$ \\
$\begin{array}{l}\text { Transition } \\
(N=6)\end{array}$ & $700-750$ & $4.75 \times 10^{-5} \pm 7.8 \times 10^{-6}$ & $9.9 \times 10^{-6} \pm 2.2 \times 10^{-6}$ & $22.66 \pm 3.9$ & $51.83 \pm 4.8$ & $6.99 \times 10^{-6} \pm 1.1 \times 10^{-6}$ \\
$\begin{array}{l}\text { Pleistocene } \\
(N=11)\end{array}$ & $850-920$ & $1.26 \times 10^{-4} \pm 8.5 \times 10^{-5}$ & $6.83 \times 10^{-6} \pm 3.0 \times 10^{-6}$ & $9.80 \pm 1.3$ & $41.0 \pm 2.7$ & $5.81 \times 10^{-6} \pm 6.2 \times 10^{-7}$ \\
\hline
\end{tabular}

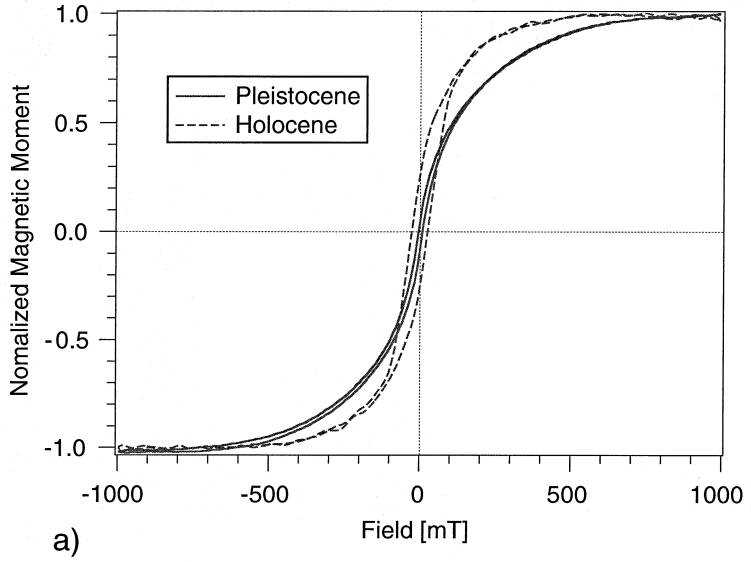

a)

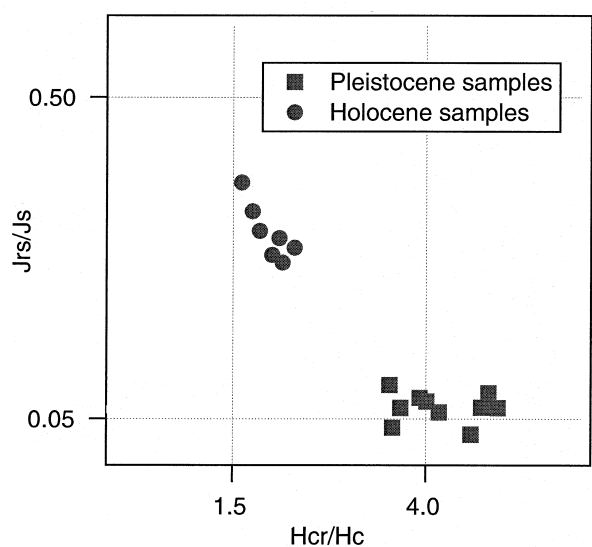

Fig. 6. Hysteresis loops of typical samples after removal of the paramagnetic contribution. The difference between samples from the 'warm' and 'cold' sections is evident from (a) the shape of the loops and (b) the hysteresis parameters plotted in a Day diagram.

$\chi_{\mathrm{hf}}$ was compared with the low-field susceptibility $\chi$ measured on a KLY-2 susceptibility bridge. The two different measurement methods gave simi- lar values which suggests that $\chi$ is mostly controlled by paramagnetic minerals.

\section{Variation of magnetic parameters with depth}

Results from the above described sediment magnetic experiments were used to choose the magnetic parameters that best reflect climatic changes. These parameters were then measured on all 500 samples to evaluate the entire core. The different IRM coercivity spectra of the Holocene and Pleistocene samples are summarized using the ratio between IRM acquired at two different fields. Instead of using the standard 'S-ratio', with a back field magnetization at $0.3 \mathrm{~T}$, we preferred to use the ratio $\operatorname{IRM}_{0.15 \mathrm{~T}} / \mathrm{IRM}_{1 \mathrm{~T}}$ [19] since the IRM in our samples was nearly saturated by $0.15 \mathrm{~T}$ (Fig. $7 \mathrm{a})$.

From the result of the zero field cooling experiment the Pleistocene samples are expected to have higher contents of SP particles compared to the Holocene sample. The concentration of the SP particles can be estimated using the ratio of the IRM acquired at low $(77 \mathrm{~K})$ and at room $(290 \mathrm{~K})$ temperature. The $\mathrm{IRM}_{290 \mathrm{~K}} / \mathrm{IRM}_{77 \mathrm{~K}}$ ratio is plotted as a function of depth in Fig. 7b.

The IRM intensity acquired in a 1-T field and the low-field susceptibility $\chi$ are plotted as functions of depth in Fig. 8a and b, respectively. $\chi$ is relatively uniform throughout the core and it does not seem to vary with the major climate change at 800 $\mathrm{cm}$; the IRM fluctuations during the Holocene are much more pronounced and may need a different interpretation.

To understand better the environmental meaning of the magnetic properties, we measured a small set 


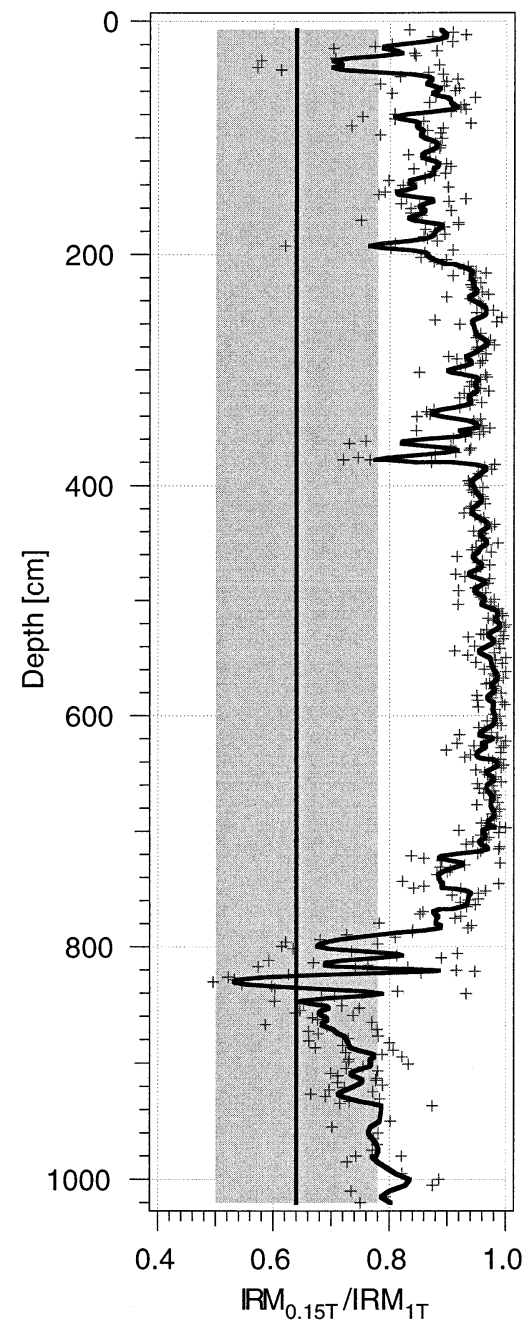

a)

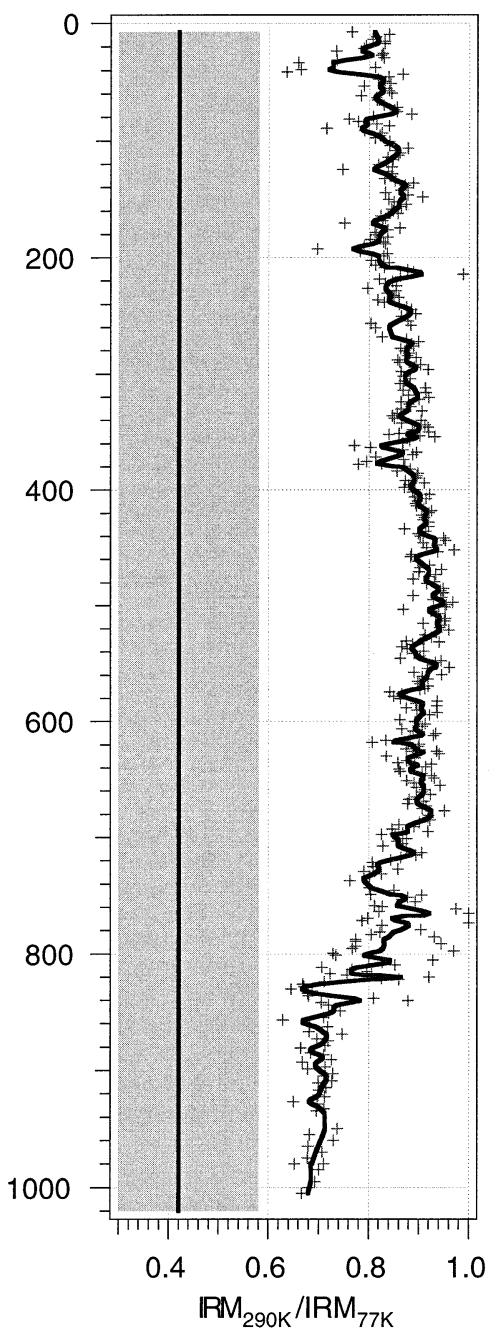

b)

Fig. 7. The ratio $\operatorname{IRM}_{0.15 \mathrm{~T}} / \mathrm{IRM}_{1 \mathrm{~T}}$ is used to show the coercivity variation of the samples as a function of depth. The ratio $\mathrm{IRM}_{290 \mathrm{~K}} / \mathrm{IRM}_{77 \mathrm{~K}}$ is used to estimate the amount of SP minerals in the samples. In this and subsequent figures the line and the grey band represent the mean and the dispersion values, respectively, of the detrital signal measured in the bedrock.

Table 2

Mean sediment magnetic parameters of bedrock samples from the Bachalpsee catchment. The dispersion parameter is the mean absolute deviation

\begin{tabular}{lllll}
\hline & $\begin{array}{l}\mathrm{IRM}_{1 \mathrm{~T}} \\
\left(\mathrm{~m}^{3} / \mathrm{kg}\right)\end{array}$ & $\mathrm{IRM}_{0.15 \mathrm{~T}} / \mathrm{IRM}_{1 \mathrm{~T}}$ & $\mathrm{IRM}_{290 \mathrm{~K}} / \mathrm{IRM}_{77 \mathrm{~K}}$ \\
\hline Mean $(N=12)$ & $1.38 \times 10^{-8} \pm 1.6 \times 10^{-8}$ & $2.0 \times 10^{-5} \pm 2.0 \times 10^{-5}$ & $0.64 \pm 0.14$ & $0.42 \pm 0.16$ \\
\hline
\end{tabular}

of samples from the bedrock of the catchment area. A summary of the bedrock properties is listed in Table 2; they are plotted together with the core data and are shown as grey bands in Figs. 7 and 8. The width of the grey band represents the variability of the catchment data. The high variability is due to the 


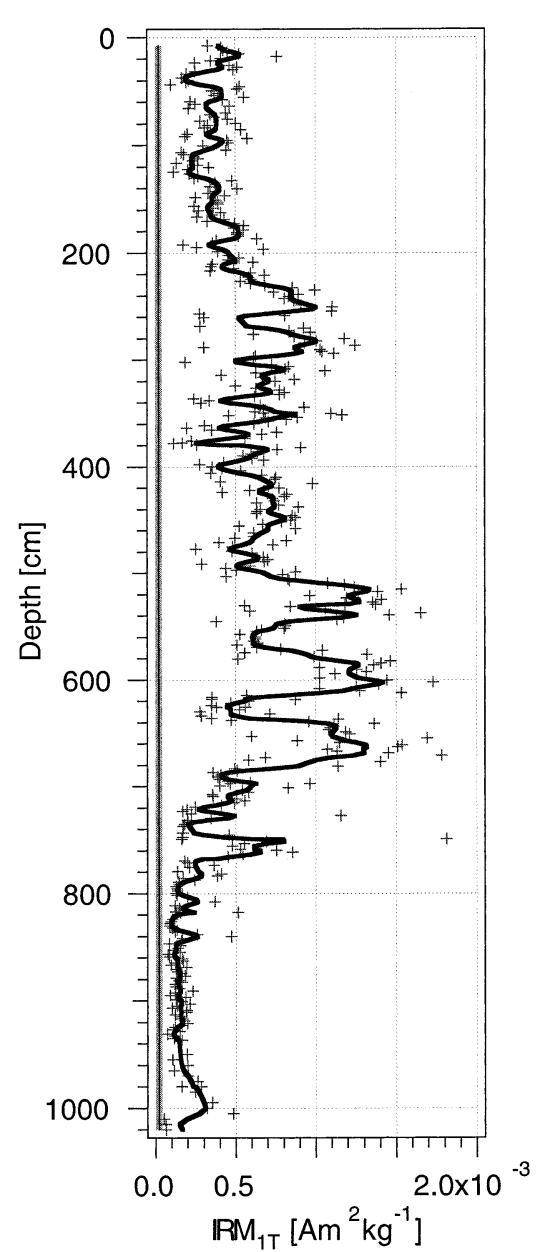

a)

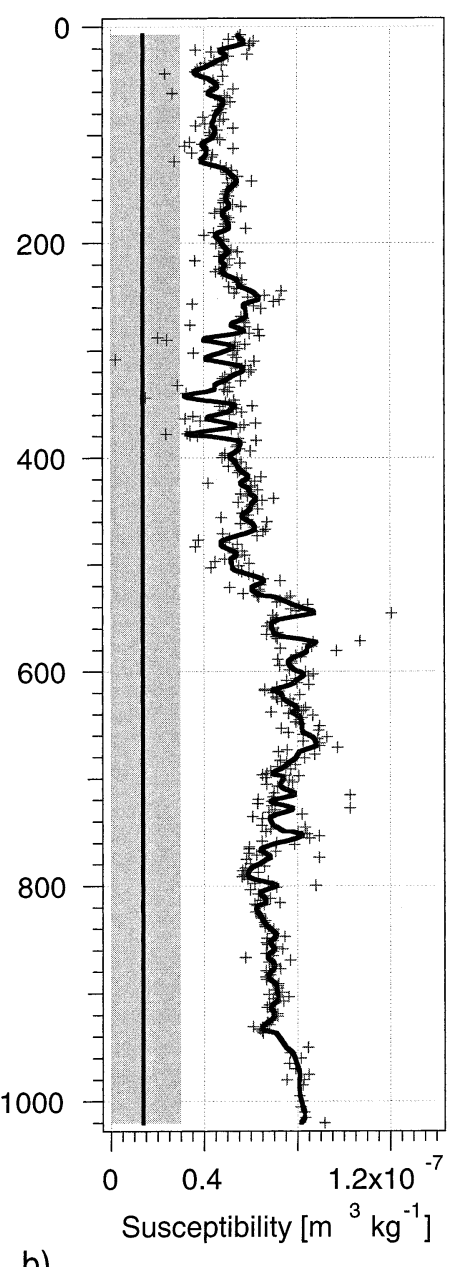

b)

Fig. 8. (a) Intensity of the IRM acquired in a $1 \mathrm{~T}$ field and (b) low field susceptibility as a function of depth.

different lithologies in the catchment. Results from the bedrock samples are assumed to approximate the properties of a purely detrital signal.

\section{Discussion and conclusions}

In the Bachalpsee sediments the most important changes of the mineral magnetic properties in response to climate are in the coercivity (Fig. 7a), due to differences in magnetic mineralogy and in the grain size distribution of the magnetic particles (Fig. 7b). The relationship with climate was verified independently, using climate-sensitive proxies such as pollen and LOI at the Holocene-Pleistocene transition. The magnetic parameters used to represent these variations $\left(\mathrm{IRM}_{0.15 \mathrm{~T}} / \mathrm{IRM}_{1 \mathrm{~T}}\right.$ and $\left.\mathrm{IRM}_{290 \mathrm{~K}} / \mathrm{IRM}_{77 \mathrm{~K}}\right)$ are not dependent on the concentration of ferromagnetic minerals. Therefore, they are not influenced by changes in productivity and sedimentation rate.

The Pleistocene (glacial) sediments are magnetically similar to the samples from the catchment bedrock, thus we deduce that these assemblages are mainly of 'detrital' origin. This conclusion agrees with sedimentological observation of a sharp change to coarse-grained sediments in the Pleistocene that indicates high erosion and detrital influx during the Late-Glacial period. Moreover, IRM intensity in the 
Pleistocene samples (i.e., the concentration of ferrimagnetic minerals) is close to values measured in the bedrock (Fig. 8a). Detrital magnetic particles seem to play an important role only during cold periods, especially during the Late-Glacial; they cannot explain the magnetic properties of the samples deposited during warm periods in the Holocene. In the Holocene sediments, the concentration of low coercivity (ferrimagnetic) minerals is always higher than both the concentration in the bedrock and in the late-glacial samples. Moreover, the magnetic mineralogy is different and there is a smaller population of SP grains. The different mineralogy and higher concentration suggest that ferrimagnetic minerals in the Holocene sediments cannot be detrital. We deduce that they have an authigenic origin. Both biogenic and chemical formation of authigenic magnetic minerals are possible in lacustrine and marine sediments [20-28], but it was not possible to discriminate between those mechanisms on the basis of magnetic properties in this study.

In the Holocene sediments, magnetite is the most important magnetic mineral. Evidence for magnetite came from measurements of coercivity, the Verwey transition, and unblocking temperatures. No evidence for a significant content of magnetic iron sulfides has been found in these sediments. In the Pleistocene sediments a high coercivity phase is also present. This is interpreted to represent hematite on the basis of coercivity and unblocking temperatures.

Variations of the IRM and $\chi$ with depth do not correlate well because the susceptibility is mainly controlled by paramagnetic minerals. Susceptibility is relatively constant throughout the core (Fig. 8b), which suggests that climate change mostly influenced the properties of ferrimagnetic and not paramagnetic minerals. The IRM intensity is not a good climate indicator in these sediments, although it is influenced by environmental changes. The concentration of ferrimagnetic minerals shows rapid fluctuations throughout the Holocene, but although different Holocene climatic oscillations have been inferred for the Alps (e.g., [29]), these fluctuations are difficult to explain in terms of climatic changes. In some cases, when high sedimentation rates are found (i.e., in the upper $400 \mathrm{~cm}$ of the core) the lower concentration of ferromagnetic (s.l.) grains can be explained by dilution due to less magnetic detrital input.
As well as the most obvious climatic transition from glacial to interglacial conditions at the Holocene-Pleistocene boundary, several small scale climatic fluctuations are known to occur during the Holocene. The smaller-scale fluctuations of $\mathrm{IRM}_{0.15 \mathrm{~T}} / \mathrm{IRM}_{1 \mathrm{~T}}$ and $\mathrm{IRM}_{290 \mathrm{~K}} / \mathrm{IRM}_{77 \mathrm{~K}}$ in the upper part of the core are also interpreted to reflect minor climatic changes. These minor variations are not evident in the pollen and LOI records, but their significance for the last 1000-1500 years can be verified by comparison with the historical climate record and other climate reconstructions (e.g., [30]). Qualitatively, these reconstructions predict a cold period spanning approximately the 9th and 10th century, followed by a warm period during the 12th century. Cold stages exist from 1300 to $1450 \mathrm{AD}$ and from 1555 to $1850 \mathrm{AD}$ with a maximum around $1750 \mathrm{AD}$. A mild period is suggested between 1450 and $1550 \mathrm{AD}[31,32]$. In Fig. 9, the $\mathrm{IRM}_{0.15 \mathrm{~T}} / \mathrm{IRM}_{1 \mathrm{~T}}$ and $\mathrm{IRM}_{290 \mathrm{~K}} / \mathrm{IRM}_{77 \mathrm{~K}}$ ratios of the upper part of the core are plotted against interpolated age. The cold periods, inferred from paleoclimatic reconstructions are marked with a black bar. Cold periods in the Bachalpsee record correspond to low values of both $\mathrm{IRM}_{0.15 \mathrm{~T}} / \mathrm{IRM}_{1 \mathrm{~T}}$ and $\mathrm{IRM}_{290 \mathrm{~K}} / \mathrm{IRM}_{77 \mathrm{~K}}$ and occur approximately at 250, 500, 1100 and 2100 radiocarbon years B.P. The three youngest episodes are in relatively good agreement with the cold periods in the historical record. The assumpion of a relatively regular sedimentation rate between the dated points may not be totally correct, which could lead to the poor match of a cold period at $450-500$ years B.P. A small cold peak, which is not reported in the historical record, is present in the $\mathrm{IRM}_{0.15 \mathrm{~T}} / \mathrm{IRM}_{1 \mathrm{~T}}$ at about 800 years B.P.; however, this peak does not have a corresponding low value in the $\mathrm{IRM}_{290 \mathrm{~K}} /$ $\mathrm{IRM}_{77 \mathrm{~K}}$, therefore it does not represent a clear indication of cooling. Particularly interesting is the clear identification of the cold period between AD 1570 and 1850, commonly called the 'Little Ice Age' [32]. The magnetic data also suggest that there was a cold period around 2100 years B.P., although no historical information is available to support this suggestion.

Human influence on land use (especially grazing) in the last 1000 years may have contributed to increased erosion in the catchment and could be responsible for the generally lower values of $\mathrm{IRM}_{0.15 \mathrm{~T}} /$ $\mathrm{IRM}_{1 \mathrm{~T}}$ and $\mathrm{IRM}_{290 \mathrm{~K}} / \mathrm{IRM}_{77 \mathrm{~K}}$ in this period. 


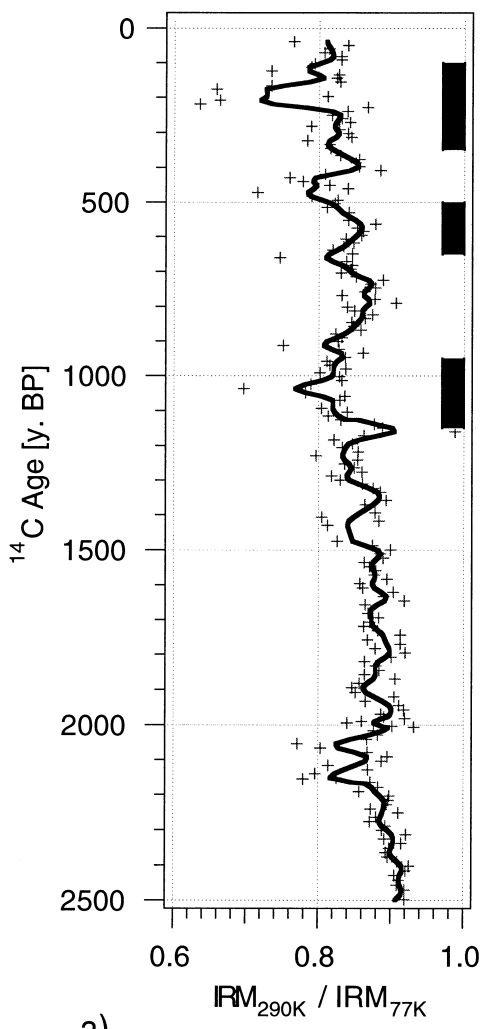

a)

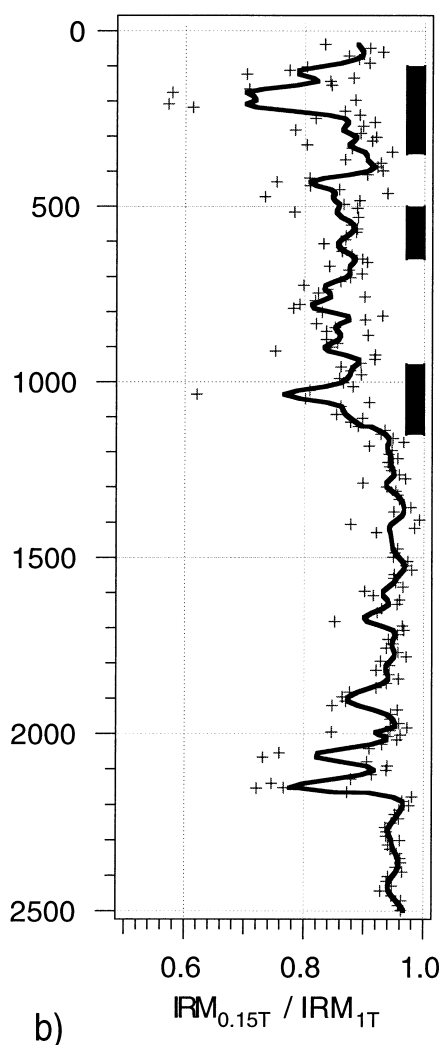

b)

Fig. 9. Magnetic parameters IRM ${ }_{290 \mathrm{~K}} / \mathrm{IRM}_{77 \mathrm{~K}}$ and $\mathrm{IRM}_{0.15 \mathrm{~T}} / \mathrm{IRM}_{1 \mathrm{~T}}$ plotted against the interpolated age. The dark bands represent cold global periods in the last 1000 years as deduced from historical and other paleoclimatic reconstructions.

In the Bachalpsee sediments there is a very good correspondence between the mineral magnetic properties and climate change, as indicated by pollen and LOI data and by the historical record. The changes in magnetic properties are likely to be caused by the climatic influence on erosional processes in the catchment, together with changes in lake water chemistry. The sediment magnetic parameters proved to be a sensitive indicator of climatic changes, being able to record the smaller variations in the Holocene climate. The Bachalpsee core thus provides a high resolution record of climatic changes in the Alpine region for the entire Holocene period.

\section{Acknowledgements}

We wish to thank the personnel of the Institute for Rock Magnetism, University of Minnesota, for making possible the low temperature measurements. We thank F. Heller, K. Kodama and A. Roberts for critically reviewing the manuscript. We gratefully acknowledge the help of C. Meile, M. Wehrli, L. Wick, I.R. Walker, and A. Zwyssig during field and laboratory sampling of the sediment core. This is publication No. 1055, Institute of Geophysics, ETHZürich.

\section{References}

[1] B. Ammann, Litho- and palynostratigraphy at Lobigensee: evidence for trophic changes during the Holocene, Hydrobiologia 143 (1986) 301-307.

[2] B. Ammann, Response times in bio- and isotope-stratigraphy to late-glacial climatic shift-an example from lake deposits, Eclogae Geol. Helv. 82 (1989) 183-190.

[3] A.F. Lotter, U. Eicher, H.J.B. Birks, U. Siegenthaler, Lateglacial climatic oscillations as recorded in Swiss lake sedi- 
ments, J. Quat. Sci. 7 (1992) 187-204.

[4] A.F. Lotter, B. Ammann, M. Sturm, Rates of change and chronological problems during the late-glacial period, Clim. Dyn. 6 (1992) 233-239.

[5] J. Bloemendal, F. Oldfield, R. Thompson, Magnetic measurements used to access sediment influx at Llyn Goddionduon, Nature 280 (1979) 50-53.

[6] K.M. Creer, T.E. Hogg, P.W. Readman, C. Reynaud, Paleomagnetic secular variation curves extending back to 13,400 years B.P. recorded by sediments deposited in Lac de Joux, Switzerland, J. Geophys. 48 (1980) 139-147.

[7] K.M. Creer, Long-period geomagnetic variations since 12,000 B.P., Nature 292 (1981) 208-212.

[8] J. Hilton, J.P. Lishman, The effect of redox changes on the magnetic susceptibility of sediments from a seasonally anoxic lake, Limnol. Oceanogr. 30 (1985) 907-909.

[9] J. Hilton, A simple model for the interpretation of the magnetic record in lacustrine and ocean sediments, Quat. Res. 27 (1987) 160-166.

[10] A.F. Lotter, B. Ammann, H.J.B. Birks, O. Heiri, A. Hirt, L. Lanci, G. Lemcke, M. Sturm, J. van Leeuwen, I.R. Walker, L. Wick, AQUAREAL: A multi-proxy study of Holocene sediment archives in alpine lakes, Würzburger Geogr. Manuskr. 41 (1997) 127-128.

[11] J. Merkt, H. Streif, Stechrohr-Bohrgeräte für limnische und marine Lockersedimente, Geol. Jahrb. 88 (1970) 137-148.

[12] B. Ammann, M.J. Gaillard, A.F. Lotter, Switzerland, in: Berglund, B.E., Birks, H.J.B., Ralska-Jasiewiczowa, M., Wright, H.E. (Eds.), Palaeoecological Events During the Last 15000 Years: Regional Syntheses of Palaeoecological Studies of Lakes and Mires in Europe, Wiley, Chichester, 1996, pp. 647-666.

[13] B. Ammann, A.F. Lotter, Late-glacial radiocarbon- and palynostratigraphy on the Swiss plateau, Boreas 18 (1989) 109-126.

[14] C.J.F. ter Braak, Ordination, in: Jongman, R.H.G., ter Braak, C.J.F., van Tongeren, O.F.R. (Eds.), Data Analysis in Community and Landscape Ecology, Pudoc, Wageningen, 1987, pp. 91-173.

[15] C.J.F. ter Braak, CANOCO - a FORTRAN program for canonical community ordination. Microcomputer Power, Ithaca, New York, 1987-1992.

[16] C.H. Reinsch, Smoothing by spline functions, Numer. Math. 10 (1967) 177-183.

[17] W. Lowrie, Identification of magnetic minerals in a rock by coercivity and unblocking temperature properties, Geophys. Res. Lett. 17 (1990) 159-162.

[18] R. Day, M. Fuller, V.A. Schmidt, Hysteresis properties of titanomagnetite: grain size and compositional dependence, Phys. Earth Planet. Int. 13 (1977) 260-267.

[19] W. Lowrie, W. Alvarez, Late Cretaceous geomagnetic polarity sequence: detailed rock and paleomagnetic studies of the Scaglia Rossa limestone at Gubbio, Italy, Geophys. J. R. Astron. Soc. 51 (1977) 561-581.

[20] J.L. Kirschvink, S.R. Chang, Ultrafine-grained magnetite in deep sea sediments: possible bacterial magnetofossils, Geology 12 (1994) 559-562.

[21] J.F. Stolz, S.R. Chang, J.L. Kirschwink, Magnetotactic bacteria and single domain magnetite in hemipalagic sediments, Nature 321 (1986) 849-851.

[22] N. Petersen, T. von Dobeneck, H. Vali, Fossil bacterial magnetite in deep-sea sediments from the South Atlantic Ocean, Nature 320 (1986) 611-615.

[23] D.G. Weiss, N. Petersen, H. Vali, Magnetic bacteria in lake sediments, in: Lowes, F.J., Collinson, D.W., Parry, J.H., Runcorn, S.K., Tozer D.C., Soward, A. (Eds.), Geomagnetism and Paleomagnetism, Kluwer Academic Press, 1989, pp. 231-242.

[24] J.F. Stolz, D.R. Lovley, S.F. Haggerty, Biogenic magnetite and the magnetization of sediments, J. Geophys. Res. 95 (1990) 4355-4361.

[25] B.M. Moskowitz, R.B. Frankel, D.A. Bazylinski, Rock magnetic criteria for the detection of biogenic magnetite, Earth Planet. Sci. Lett. 120 (1990) 283-300.

[26] T.B. Hawthorne, J. McKenzie, Biogenic magnetite: authigenesis and diagenesis with changing redox conditions in Lake Greifen, Switzerland, in: Aissoui, D.M., McNeill, D.F., Hurlei, N.F. (Eds.), Application of Paleomagnetism to Sedimentary Geology, SEPM Spec. Publ. 49, Society for Sedimentary Geology, 1993.

[27] P.P. Hesse, Evidence for bacterial paleoecological origin of mineral magnetic cycles in oxic and sub-oxic Tasman Sea sediments, Mar. Geol. 117 (1994) 1-17.

[28] I.F. Snowball, Bacterial magnetite and the magnetic properties of sediments in a Swedish lake, Earth Planet. Sci. Lett. 126 (1994) 129-142.

[29] L. Wick, W. Tinner, Vegetation changes and timberline fluctuations in the Central Alps as indicators of Holocene climaticoscillations, Arct. Alp. Res. 29 (1997) 445-458.

[30] R.S. Bradley, Quaternary Paleoclimatology, Allen and Unwin, London, 1985.

[31] P.D. Jones, The climate of the past 1000 years, Endeavour, New Ser. 14 (1990) 129-136.

[32] R.S. Bradley, P.D. Jones, 'Little ice age' summer temperature variations: their nature and relevance to recent global warming trends, Holocene 3 (1993) 367-376. 